\title{
OBITUARY
}

\section{PROFESSOR ARTHUR ERDÉLYI}

The world of mathematics suffered a great loss with the sudden death, on 12th December 1977, of Professor Arthur Erdélyi, F.R.S.

Arthur Erdélyi was born on 2nd October 1908 in Budapest, Hungary, and received primary and secondary education there from 1914 to 1926. Due to circumstances then obtaining in Hungary, his tertiary education was not undertaken there but in Brno, Czechoslovakia, and after an initial training in Electrical Engineering his remarkable talent for mathematics became evident. His active research in this area began about 1930 and under normal circumstances, a career in professional mathematics in Czechoslovakia would have been assured.

Circumstances were far from normal and the German occupation of Czechoslovakia in 1938 put him, as a Jew, in mortal danger. It was largely due to Sir Edmund Whittaker that he was able to come to Edinburgh in 1939 as the poignant correspondence between him and Whittaker, much of which is fortunately preserved, gives grim testimony. Nor were his fears groundless as two brothers and a sister were later to die in concentration camps but it is pleasing to record that his mother survived and lived in Israel for many years after the war and that Arthur was always a most devoted son.

His connection with the California Institute of Technology (Caltech) began in 1947 and after returning to Edinburgh for the year 1948-49 he returned as a full professor to Caltech in 1949, a position he occupied with great distinction until 1964 when, to the delight of his many friends in Edinburgh and elsewhere in Scotland, he returned to the University of Edinburgh where he eventually occupied the famous Chair of Mathematics held once by McLaurin and in more recent years by Whittaker and Aitken. That he was a worthy successor to his illustrious predecessors is its own tribute.

He had gone originally to Caltech to examine and transcribe research notes on Special Functions left by the late Harry Bateman and the five volumes on Higher Transcendental Functions and Integral Transforms, produced by an international team of mathematicians under his direction, remain an abiding testimony to his technical skill and sheer professional competence. Yet it is not for this that Arthur Erdélyi would best wish to be remembered. The fifteen years he spent in California from 1949 onwards saw him at the height of his mathematical powers. Already an expert in classical asymptotic analysis, he was quick to see the significance of the fast developing theory of strained coordinates and matched asymptotic expansions and became deeply involved in the powerful researches then going on in this field at Caltech. Another topic in which he had a long interest was that of Generalised Functions. In some ways this was particularly well suited to his talents as it enabled his powerful analytical mind to range over the whole spectrum of mathematics from the subtlest arguments in pure mathematics to the pragmatic applications required by the engineer. In these and other areas, his extensive list of publications testifies to the breadth and depth of his mathematical knowledge.

To Arthur Erdélyi over the years were accorded the academic honours that were his 
due. In 1940 he was awarded the degree of D.Sc.(Edin.). He was elected a Fellow of the Royal Society of Edinburgh in 1945, a Foreign Member of the Academy of Sciences of Torino in 1953, and a Fellow of the Royal Society of London in 1975. In 1977 he was awarded the Gunning Victoria Jubilee Prize of the Royal Society of Edinburgh, the only mathematician to receive it in recent years other than Sir William Hodge. He attracted many invitations to visit mathematical centres elsewhere and travelled widely and lectured frequently in Europe, North America and Australia and visited Israel on several occasions. Members of the Edinburgh Mathematical Society will recall with pleasure his deep interest in the Society of which he was President in the academic year 1971-72.

I am fortunate in having known Arthur Erdélyi over a period of more than thirty years during most of which we were at least in correspondence if not in contact. I remember well his lectures at Edinburgh when I was an undergraduate just after the war; I recall the awe in which, with a little more mathematical maturity, 1 held him when I was a postdoctoral fellow at Caltech in the mid-fifties when he seemed to dominate the whole mathematical scene; and I look back with pleasure and satisfaction at our association as colleagues in the University of Edinburgh since 1968.

The most lasting impression which I retain of him as a mathematician is the astonishing range of his interests. There seemed almost no subject in mathematics about which he could not talk with authority, backed up by extensive references to the relevant literature and often accompanied by an anecdote reflecting his personal experience and involvement. His command of English was exceptional and all the more remarkable as he was in his thirties before it became a familiar tongue. Outside mathematics he was astonishingly well informed on a tremendous variety of topics. He spelt out his philosophy with characteristic clarity in his inaugural lecture in 1965 when he said:

"It is of the essence of a University that intellectual contact between its constituent parts should be fostered. I sometimes despair of the possibility of explaining modern mathematics to friends without a technical mathematical training, but this does not prevent me from trying again and again. In the same spirit, I am desirous of hearing of happenings in other areas of scholarship in the firm belief that learning about such developments makes me not only a more informed human being, but also a better mathematician."

He was above all a scholar who made no compromise with the highest standards of his profession. But he was more. He was an intensely human person with a keen sense of humour and a great love of art, of music, of the countryside and of children. It is impossible in a few short paragraphs to give a proper impression but to those who were privileged to know him and whose lives he touched, he will always remain an unforgettable figure.

A. G. MACKIE 